SJ Quinney College of Law, University of Utah Utah Law Digital Commons

Utah Law Faculty Scholarship

Utah Law Scholarship

4-13-2017

\title{
A New Perspective on FRAND Royalties: Unwired Planet v. Huawei
}

Jorge L. Contreras

University of Utah, jorge.contreras@law.utah.edu

Follow this and additional works at: http://dc.law.utah.edu/scholarship

Part of the Intellectual Property Law Commons

\section{Recommended Citation}

Contreras, Jorge L., "A New Perspective on FRAND Royalties: Unwired Planet v. Huawei" (2017). Utah Law Faculty Scholarship. 42. http://dc.law.utah.edu/scholarship/42

This Article is brought to you for free and open access by the Utah Law Scholarship at Utah Law Digital Commons. It has been accepted for inclusion in Utah Law Faculty Scholarship by an authorized administrator of Utah Law Digital Commons. For more information, please contact valeri.craigle@law.utah.edu. 
Draft for Comment: 13 Apr 2017

Jorge L. Contreras ${ }^{1}$

In Unwired Planet v. Huawei, ${ }^{2}$ Mister Justice Colin Birss of the UK High Court of Justice (Patents) has issued a detailed and illuminating opinion regarding the assessment of royalties on standards-essential patents (SEPs) that are subject to FRAND (fair, reasonable and nondiscriminatory) licensing commitments. Among the important and potentially controversial rulings in the case are (1) there is but a single FRAND royalty rate applicable to any given set of SEPs and circumstances, (2) neither a breach of contract nor a competition claim for abuse of dominance will succeed unless a SEP holder's offer is significantly above the true FRAND rate, (3) FRAND licenses for global market players are necessarily global licenses and should not be limited to a single jurisdiction, and (4) the "non-discrimination" (ND) prong of the FRAND commitment does not imply a "hard-edged" test in which a licensee may challenge the FRAND license that it has been granted on the basis that another similarly situated licensee has been granted a lower rate, so long as the difference does not distort competition between the two licensees. This case should prove important, particularly as courts around the world wrestle with the increasing assertion of SEPs by patent assertion entities (PAEs) ${ }^{3}$ and the transfer of SEPs from producing firms to PAEs (a phenomenon referred to as privateering). ${ }^{4}$

\section{Background}

This case began in 2014 when Unwired Planet, a U.S.-based patent assertion entity, sued Google, Samsung and Huawei for infringement under six UK patents (corresponding actions were filed in Germany). Unwired Planet claimed that five of the asserted patents, which it acquired from Ericsson in 2013 as part of a portfolio comprising approximately 2,000 patents, ${ }^{5}$ were essential to the $2 \mathrm{G}, 3 \mathrm{G}$ and $4 \mathrm{G}$ wireless telecommunications standards developed under the auspices of the European Telecommunications Standards Institute (ETSI). Because Ericsson participated in development of the standards at ETSI, any patents shown to be SEPs would necessarily be encumbered by Ericsson's FRAND commitment to ETSI.

\footnotetext{
${ }^{1}$ Associate Professor, University of Utah S.J. Quinney College of Law. Please send comments, suggestions and corrections to jorge.contreras@law.utah.edu. An earlier version of this paper appeared in the PatentlyO Blog on Apr. 10, 2017, https://patentlyo.com/patent/2017/04/unwired-perspective-royalties.html.

2 [2017] EWHC 711 (Pat) (Apr. 5, 2017).

${ }^{3}$ See, e.g., Jorge L. Contreras, Fabian Gaessler, Christian Helmers, and Brian Love Litigation of StandardsEssential Patents in Europe: A Comparative Analysis, _ BERKELEY TECH. L.J. _ (2017, forthcoming) (describing SEP assertions in UK and Germany, noting high levels of assertion by NPEs); Jorge L. Contreras, When a Stranger Calls: Standards Outsiders and Unencumbered Patents, 12(3) J. COMPETITION L. \& ECON. 507 (2016) (describing high levels of SEP assertion in U.S. litigation).

${ }^{4}$ See, e.g., John M. Golden, Patent Privateers: Private Enforcement's Historical Survivors, 26 HARV. J. L. \& TECH. 545 (2013); Erik Hovenkamp \& Thomas F. Cotter, Anticompetitive Patent Injunctions, 100 MinN. L. REV. 871 (2016).

${ }^{5}$ See Master Sale Agreement dated Jan. 10, 2013 between Telefonaktiebolaget L M Ericsson and Cluster et al., available at https://www.sec.gov/Archives/edgar/data/1082506/000119312513012058/d466328dex102.htm . See also Florian Mueller, Ericsson's pseudo-sale of patents to Unwired Planet and the rampant problem of privateering, FOSS Patents, Apr. 21, 2015, available at http://www.fosspatents.com/2015/04/ericssonspseudo-sale-of-patents-to.html .
} 
The UK proceedings involved numerous stages, including five scheduled "technical trials" which would determine whether each of the asserted patents was valid, infringed and essential to the ETSI standards. During these proceedings Google and Samsung settled with Unwired Planet and Ericsson (which receives a portion of the licensing and settlement revenue earned by Unwired Planet from the patents), leaving Huawei as the sole UK defendant. By April 2016 three of the technical trials had been completed, resulting in findings that two of the asserted patents were invalid and that two were both valid and essential to the standards. These findings are currently under appeal. The parties then agreed to suspend further technical trials. In October 2016 a "non-technical" trial began regarding issues of competition law, FRAND, injunction and damages. Hearings were concluded in December 2016, and the court's opinion and judgment were issued on April 5, 2017.

\section{A. The High Court's Decision - Overview}

The principal questions before the court in Unwired Planet were (1) the level of the FRAND royalty for Unwired Planet's SEPs, (2) whether Unwired Planet abused a dominant position in violation of Section 102 of the Treaty for the Formation of the European Union (TFEU) by failing to adhere to the procedural requirements for FRAND negotiations outlined by the European Court of Justice (CJEU) in Huawei v. ZTE, ${ }^{6}$ and (3) whether an injunction should issue in the case. In the below discussion.

\section{B. FRAND Commitments - General Observations}

Birss, J. begins with some general observations and background about the standard-setting process and FRAND commitments. A few notable points emerge from this discussion.

1. ETSI and French law. FRAND commitments in standard-setting arise from the voluntary commitments made by participants in the standards-development process. These commitments are largely the result of written policies adopted by standards-development organizations (SDOs). There is considerable academic debate regarding the legal treatment of these commitments, and whether they can and should be enforceable as contractual commitments: not by the SDO, but by third party implementers of the SDO's standards. ${ }^{7}$

Given this context, it is an inconvenient fact, at least to international commentators, that ETSI, one of the principal global SDOs, is chartered under French law, and that French legal principles govern its membership and policy documentation. ${ }^{8}$ In recent cases involving ETSI standards, several non-French courts, particularly in the U.S., have studiously avoided any deep engagement with French law in considering these questions. The most notable instance of such evasion occurred in Apple, Inc. v. Motorola Mobility, Inc., ${ }^{9}$ in which the trial judge concluded, on the basis of a single affidavit, that French law "requires the same general elements" as Wisconsin law, and made little effort to apply anything other than local law to the case. ${ }^{10}$

\footnotetext{
${ }^{6}$ Case C-170/13, 16 th July 2015 [2015] Bus LR 1261.

${ }^{7}$ See Jorge L. Contreras, A Market Reliance Theory for FRAND Commitments and Other Patent Pledges, 2015 UTAH L. REV 479, 508-14 (2015) (discussing and questioning third party beneficiary theory as applied to contractual FRAND commitments).

${ }^{8}$ European Telecom. Standards Inst., ETSI Rules of Procedure, Sec. 12 - Law and Regulation ("This Policy shall be governed by the laws of France.")

${ }^{9} 886$ F.Supp.2d 1061 (W.D. Wis. 2012).

${ }^{10} I d$. at 1083 .
} 
To his credit, Birss, J. undertakes a thorough analysis of French statutory law as applied to ETSI's FRAND commitments, thoughtfully probing the arguments of both parties' experts. ${ }^{11}$ And while he concedes that, as a theoretical matter, "the enforceability of the FRAND undertaking in French law is not a clear cut question", ${ }^{12}$ he adopts the pragmatic view that FRAND commitments should in any event be viewed as "public, irrevocable and enforceable" on grounds of public policy, if nothing else. ${ }^{13}$

2. A Single FRAND Rate. In an earlier case, Vringo v. ZTE $E^{14}$, Birss, J. considered the possibility that a SEP holder and a standard implementer could each make the other a FRAND licensing offer, resulting in two competing FRAND offers or a range of possible royalty rates that could qualify as FRAND. In Unwired Planet, Birss, J. reconsiders this possibility, reasoning that it is far better to maintain, as a matter of law, that there is but a single royalty rate that qualifies as FRAND for any given set of SEPs and products. ${ }^{15}$ From a practical standpoint, this approach solves several problems, including how to evaluate the conduct of the parties from a competition law standpoint. In rejecting the parties' objections to this approach, he makes two additional observations. First, if there is but a single precise value for the FRAND royalty, it is likely that parties, in private bilateral negotiations over SEP licenses, will agree on some royalty rate that differs from this precise value. This likelihood does not, however, open up every negotiated agreement to a FRAND-based challenge, as the parties are free to agree on any royalty they wish, absent competition law considerations. ${ }^{16}$

I am not wholly convinced by this reasoning. In essence, the court holds that while the FRAND rate is precise, the conditions under which it may be enforced are fuzzy. This conclusion results in a number of additional logical hurdles, discussed below, with respect to the SEP holder's initial offer to the implementer and how to assess the SEP holder's compliance with competition law. An alternative approach that avoids these problems is the one developed by Judge James Robart in Microsoft Corp. v. Motorola, Inc. ${ }^{17}$ There, the court determined a FRAND range for the SEPs covering each standard at issue in order to assess the SEP holder's compliance with its FRAND commitment. Then, in setting a final royalty, the court picked a specific rate within the allowable range. This approach seems more in keeping with the parties' intent during standard-setting, and creates a more definite framework for assessing the parties' compliance with their FRAND commitments.

3. FRAND means Worldwide. Unwired Planet offered Huawei a worldwide license under the asserted SEPs. Huawei responded that it only wanted a license under Unwired Planet's UK patents, ${ }^{18}$ and that Unwired Planet's insistence on a worldwide license was unreasonable. In evaluating the reasonableness of Unwired Planet's worldwide license offer, Birss, J. first observed that "the vast majority" of SEP licenses in the industry, including all of the comparable licenses introduced at trial, were granted on a worldwide basis. ${ }^{19}$ He then observed that Unwired

${ }^{11}$ Unwired Planet at $\mathbf{9 1}$ 103-146.

${ }^{12}$ Unwired Planet at $\uparrow 146$.

${ }^{13}$ Id. See also Contreras, Market Reliance, supra note 7, at 486-90 (discussing inherently public nature of FRAND commitments) and Jorge L. Contreras, From Private Ordering to Public Law: The Legal Framework Governing Standards-Essential Patents, 30 HARV. J.L. \& TECH. 211 (2017).

${ }^{14}$ [2013] EWHC 1591 (Pat) and [2015] EWHC 214 (Pat.).

${ }^{15}$ Unwired Planet at $\$ 804(4)$.

${ }^{16}$ Unwired Planet at 9155 . See also Part C, infra.

${ }^{17} 963$ F. Supp. 2d 1176 (W.D. Wash. 2013).

${ }^{18}$ Unwired Planet at 9524.

${ }^{19}$ Unwired Planet at $₫ 534$. 
Planet's patents were issued in forty-two countries, while Huawei's operations extended to fiftyone countries. ${ }^{20}$ In effect, both are global companies. Against this backdrop, he concluded that "a licensor and licensee acting reasonably and on a willing basis would agree on a worldwide licence". ${ }^{21}$ In contrast, he regards the possibility of country-by-country licensing as highly inefficient. ${ }^{22}$ The prospect of two large multinational companies agreeing to country-bycountry licensing, he concludes, would be "madness", ${ }^{23}$ and that Huawei's insistence on a UKonly license is not FRAND. ${ }^{24} \mathrm{He}$ likewise dismisses Huawei's arguments that including unwanted patents from certain countries in its portfolio amounts to illegal tying in violation of competition law. ${ }^{25}$ Accordingly, he rules that, in this case, a FRAND license is necessarily a worldwide license.

4. FRAND Requires Granting a License, not Merely Offering FRAND Terms. It has long been a point of debate whether a FRAND commitment requires a SEP holder to offer FRAND terms to a potential licensee, or actually to enter into a license on FRAND terms. ${ }^{26}$ Birss, J. answers this question in a novel manner. Bearing in mind his earlier conclusion that there is only one FRAND rate under a given set of circumstances, if the SEP holder's obligation were merely to make an offer at the FRAND rate, then the normal process of negotiation "would condemn patentees to always end up with negotiated rates below a FRAND rate". ${ }^{27}$ Under this reasoning, it would seem that the SEP holder would be justified in making an initial offer above the FRAND rate, so that the final negotiated rate ended up being FRAND. This approach seems a dangerous one, as SEP holders may not always negotiate a rate downward, particularly when they use a standard set of rates (which is advisable given the nondiscrimination commitment that also makes up part of a FRAND commitment). Thus, this leniency seems to support higher (and supra-FRAND) offers by SEP holders. More sensible, I believe, is Judge Robart's approach in Microsoft v. Motorola, in which FRAND represents a range of reasonable royalties into which the SEP holder's initial offer must fall.

\section{The FRAND Negotiation Process and Competition Law}

1. SEP Holder's Offer. In Huawei v. ZTE, the CJEU established a set of procedures that a SEP holder must comply with when negotiating a FRAND license in order to avoid a finding that it abused its dominant position under TFEU Section 102. To do so, based on the rulings of the CJEU and lower courts in Germany and other EU countries, practitioners and commentators have assumed that in order to avoid a finding of abuse of dominance, a SEP holder must make an initial FRAND offer to a potential licensee. However, under Birss, J.'s reasoning that there is only a single FRAND rate in a given transaction, requiring the SEP holder to offer this rate at the outset would not be reasonable. Thus, Birss, J. concludes that it would not be an abuse of dominance under TFEU 102 or the CJEU's holding in Huawei v. ZTE for a SEP holder to offer a rate that is different from the precise FRAND rate, so long as it is

\footnotetext{
${ }^{20}$ Unwired Planet at 9538.

${ }^{21}$ Unwired Planet at 9543.

${ }^{22}$ Unwired Planet at $\$ 544$.

${ }^{23}$ Unwired Planet at $\$ 543$.

${ }^{24}$ Unwired Planet at $\$ 572$.

${ }^{25}$ Unwired Planet at $99545-572$.

${ }^{26}$ See Contreras, Market Reliance, supra note 7, at 497-98 (discussing distinction between "process obligtations" and "content obligations").

${ }^{27}$ Unwired Planet at $₫ 159$.
} 
not excessively so. ${ }^{28}$ That is, an abuse of dominance will not be found unless an offer "is so far above FRAND as to act to disrupt or prejudice the negotiations themselves". ${ }^{29}$

2. Hold-out. Birss, J. also addresses the behavior of the potential licensee in these negotiations. If the licensee engages in deliberate delay tactics or other unreasonable behavior to avoid entering into a license (and thus paying royalties), this is referred to as hold-out or reverse hold-up. Birss, J. views the behavior of the potential licensee as relevant in determining whether, from a competition law standpoint, the SEP holder possesses a dominant position. ${ }^{30}$ Interestingly, however, Birss, J. reasons that evidence of implementer holdout is really only relevant before pricing discussions began. "Once prices are discussed a delay may just be due to a licensor asking for too much money". 31

\section{Non-Discrimination}

The non-discrimination (ND) prong of the FRAND commitment is important, but has received far less attention from courts than other issues. Birss, J. devotes substantial space to the non-discrimination arguments made by the parties, and develops some novel theories in doing so.

1. Similarly-Situated Licensees. There is general consensus (including among the experts in this case) that in order to comply with the non-discrimination prong of the FRAND commitment, a SEP holder must treat "similarly situated" licensees in a similar manner. ${ }^{32}$ Several commentators have understood this constraint to allow a SEP holder to charge different royalty rates to implementers based on their size or market share (often with the understanding that larger players are likely to sell more licensed products and thus pay higher levels of royalties). ${ }^{33}$ Birss, J., however, reasons that a FRAND royalty rate should be set based on the value of the licensed patents, not on the size of other characteristics of the licensee. ${ }^{34}$ Thus, "all licensees who need the same kind of licence will be charged the same kind of rate" (id.) and "[s]mall new entrants are entitled to pay a royalty based on the same benchmark as established large entities". ${ }^{35}$ This attempt to level the playing field for new market entrants is a positive development, as this issue is currently being debated in other FRAND cases around the world.

2. Hard-Edged Non-Discrimination. But despite bolstering the non-discrimination commitment by eliminating size-based discrimination, Birss, J. then weakens it by holding that a licensee cannot challenge a license allegedly granted on FRAND terms if it later discovers that a similarly-situated implementer received a lower royalty rate unless the difference would "distort competition" between the two licensees. ${ }^{36}$ In reaching this conclusion, he rejects the notion that the ND prong of FRAND implies a "hard-edged" obligation that establishes a ceiling on the rate that a SEP holder may charge. Birss, J. justifies this conclusion under a competition law

\footnotetext{
${ }^{28}$ Unwired Planet at $\$ 153$.

${ }^{29}$ Unwired Planet at 9765.

${ }^{30}$ Unwired Planet at $₫ 806(12)$.

${ }^{31}$ Unwired Planet at $₫ 667$.

${ }^{32}$ Unwired Planet at 9485.

33 See, e.g., Richard J. Gilbert, Deal or No Deal? Licensing Negotiations in Standard-Setting Organizations, 77 AnTitRust L.J. 855 (2011); Dennis W. Carlton and Allan L. Shampine, An Economic Interpretation of FRAND, 9 J. COMPETITION L. \& ECON. 531 (2013).

${ }^{34}$ Unwired Planet at $\$ 175$.

${ }^{35}$ Unwired Planet at $9806(8)$.

${ }^{36}$ Unwired Planet at $\$ 501$.
} 
rationale, noting that a competition law violation would not occur without a competitive distortion. This reasoning, however, seems to conflate two issues: the competition law effects of violating a FRAND commitment, and the private "contractual" meaning of the FRAND commitment itself. I am uncertain whether the participants in an SDO would interpret the nondiscrimination prong of FRAND to allow discrimination between similarly situated licensees. While a competition law violation might not arise absent some distortion to competition, I believe that the underlying contractual meaning of FRAND must impose a stricter definition of non-discrimination that would prevent all but the most inconsequential differences between similarly situated licensees.

\section{E. FRAND Royalty Calculation Methodology}

Perhaps the most significant aspect of Birss, J.'s opinion in Unwired Planet is his careful calculation of the FRAND royalty applicable to the parties' transaction. He offers two possible methods of calculating the FRAND royalty, one based on an analysis of comparable license rates, the other based on a top-down analysis of the total aggregate royalty that should be attributable to the standards and SEPs at issue. Both of these methods are discussed in greater detail below. What is most refreshing about Birss, J.'s opinion, however, is the absence of any attempted application of the 15-factor Georgia-Pacific framework for "reasonable royalty" patent damages,${ }^{37}$ which U.S. courts feel compelled to apply despite the fact that a FRAND royalty calculation is not a remedial damages calculation. ${ }^{38}$ Without the baggage of Georgia-Pacific to clutter the analytical exercise, Birss, J. can focus on the actual task at hand: computing the value of the patented technology as compared to the standard and product at issue.

1. No ex ante valuation. In addition to disregarding the U.S. GeorgiaPacific framework, which clearly has no place in a UK decision, Birss, J. rejects another touchstone of U.S. FRAND analysis: the notion that a FRAND royalty should reflect the ex ante value of the patented technology, without considering any value attributable to the adoption of the technology in a standard. This theoretical construct, which has its basis in economic analysis, has been adopted by scholars, ${ }^{39}$ regulatory agencies ${ }^{40}$ and courts in the U.S. ${ }^{41}$ It has, however, come under increasing criticism by commentators who advocate ceding at least part of the value of standardization to the SEP holder. ${ }^{42}$ In rejecting the ex ante valuation approach Birss, J. acknowledges that he is departing from the decisions of U.S. courts in cases such as Innovatio and Ericsson v. D-Link. ${ }^{43}$ In the end, however, he notes that the point is moot, as neither party pressed to use this approach.

${ }^{37}$ Georgia-Pacific Corp. v. U.S. Plywood Corp., 318 F. Supp. 1116, 1120 (S.D.N.Y. 1970), modified and aff'd, 446 F.2d 295 (2d Cir. 1971).

${ }^{38}$ See Jorge L. Contreras \& Richard J. Gilbert, A Unified Framework for RAND and other Reasonable Royalties, 30 BERKELEY TECH. L.J. 1451 (2015) (criticizing use of Georgia-Pacific framework for FRAND royalty analysis).

${ }^{39}$ See, e.g., Mark A. Lemley \& Carl Shapiro, Patent Holdup and Royalty Stacking, 85 TEX. L. REV. 1991 (2007); Joseph Farrell, et al., Standard Setting, Patents, and Hold-Up, 74 ANTITRUST L.J. 603, 603 (2007).

${ }^{40}$ Fed. Trade Comm'N, The Evolving IP Marketplace: Aligning Patent Notice and Remedies WITH COMPETITION 22-23 (2011) ("A definition of RAND based on the ex ante value of the patented technology at the time the standard is chosen is necessary for consumers to benefit from competition among technologies to be incorporated into the standard").

${ }^{41}$ Ericsson v. D-Link, 773 F.3d at 1232.

${ }^{42}$ See, e.g., Norman Siebrasse and Thomas F. Cotter, The Value of the Standard, 101 Minn. L. Rev. 1159 (2017); J. Gregory Sidak, Apportionment, FRAND Royalties, and Comparable Licenses after Ericsson v. D-Link, _ U. Ill. L. Rev. (forthcoming).

${ }^{43}$ Unwired Planet at 997. 
2. Comparables Method. Like many U.S. judges, Birss, J. relies heavily on comparable license agreements to determine a FRAND royalty. While the use of comparable licenses has been criticized on the basis that most licenses are not really comparable to the desired FRAND license, ${ }^{44}$ the fact that Unwired Planet obtained each of the asserted patents from Ericsson was convincing proof that at least Ericsson's licenses were comparable to whatever Unwired Planet would have negotiated with Huawei. ${ }^{45}$ Indeed, Birss, J. found that most other licenses (i.e., not involving Ericsson) proffered by the parties were not suitable comparables.

After identifying a suitable set of comparable Ericsson licenses, Birss, J. reasoned that the appropriate FRAND royalty rate for Unwired Planet's $2 \mathrm{G} / 3 \mathrm{G} / 4 \mathrm{G}$ SEP portfolio should be the rate charged by Ericsson for its $2 \mathrm{G} / 3 \mathrm{G} / 4 \mathrm{G}$ SEP portfolio, multiplied by a factor representing the relative strength of Unwired Planet's portfolio to Ericsson's. ${ }^{46}$ Using these inputs, he calculates the FRAND rates for Unwired Planet's portfolio as follows: ${ }^{47}$

a) 4G/LTE: $0.062 \%$ for handsets, and $0.072 \%$ for infrastructure;

b) $3 \mathrm{G} / \mathrm{UMTS}: 0.032 \%$ for handsets, and $0.016 \%$ for infrastructure;

c) $2 \mathrm{G} / \mathrm{GSM}: 0.064 \%$ for handsets, and $0.064 \%$ for infrastructure.

While this calculation results (as shown below) in a FRAND rate that is validated through other methods, it is questionable whether this methodology (which is dependent on having a comparable license under which the asserted SEPs were previously licensed) has significant applicability to other cases. That is, FRAND rates in cases such as Microsoft $v$. Motorola and Ericsson v. D-Link could not have been calculated as simply or reliably as the rate in Unwired Planet because there did not exist an original SEP owner that sold a subset of its SEPs to the licensor in the case. Thus, the straightforward apportionment of a fraction of the overall Ericsson portfolio to Unwired Planet would not have worked when Motorola or Ericsson itself was the licensor. As such, the court in Unwired Planet may simply have been the beneficiary of good luck in having at hand such a clear set of comparable licenses. This being said, the individual circumstances of a case are always key to resolving it, and I have previously observed that similar good fortune (in the availability of patent pools covering the standards at issue) played a significant role in establishing patent pool values as comparables in Microsoft $v$. Motorola, another well-reasoned decision. ${ }^{48}$

3. Top-Down Methodology. In addition to the comparables method described above, Birss, J. uses a second FRAND calculation methodology as a "cross-check" of the result obtained using the comparables methodology. ${ }^{49}$ This is a "top down" or "aggregate royalty burden" approach, in which the aggregate royalty attributable to a standard under all SEPs is computed and then allocated to the SEP holder in suit. This approach has been advocated by

${ }^{4}$ See, e.g., Jonathan S. Masur, The Use and Abuse of Patent Licenses, 110 Nw. U. L. REV. 115 (2015). But see Colleen Chien and Eric Schulman, Patent Semi-Comparables, _ TEX. InTELL. Prop. L.J. (forthcoming) (arguing that many license comparisons may be useful in patent royalty calculations, even if facts are not identical from transaction to transaction).

${ }^{45}$ Unwired Planet at $\$ 180$.

${ }^{46}$ Unwired Planet at $\$ 807(4),(7)$.

${ }^{47}$ Unwired Planet at $\$ 807(8)$.

${ }^{48}$ See Jorge L. Contreras, So That's What RAND Means? A Brief Report on the Findings of Fact and Conclusions of Law in Microsoft v. Motorola, Patently-O blog, Apr. 27, 2013.

${ }^{49}$ Unwired Planet at $\$ 476$. 
commentators $^{50}$ and has been attempted in cases including Innovatio, ${ }^{51}$ as well as the Japanese IP High Court's decision in Apple Japan v. Samsung. ${ }^{52}$

Under the top down method defined by Birss, J., the FRAND royalty equals $\mathbf{T} \mathbf{x} \mathbf{S}$, where $\mathbf{T}$ is the total aggregate SEP royalty burden of a particular standard on a product (i.e., the percentage of a smartphone's price that should be charged for all patents covering $4 \mathrm{G}$ ), and $\mathbf{S}$ is the share of that aggregate royalty that is allocable to the SEP holder (Unwired Planet). ${ }^{53}$ To calculate "T", Birss, J. considered public statements made by Ericsson and other holders of SEPs covering the relevant standards. ${ }^{54}$ He then calculated "S", Unwired Planet's share of the relevant SEPs, using a variety of counting and filtering methodologies proposed by the parties' experts, including a filter for the likely essentiality of the patents in the asserted portfolio. ${ }^{55}$ The resulting FRAND rates served as validating cross-checks for the rates obtained using the Comparables methodology.

\section{F. Injunctive Relief}

The court concludes with a brief discussion of the injunctive relief requested by Unwired Planet: "Since Unwired Planet have established that Huawei have infringed valid patents ... and since Huawei have not been prepared to take a licence on the terms I have found to be FRAND, and since Unwired Planet are not in breach of competition law, a final injunction to restrain infringement of these two patents by Huawei should be granted". ${ }^{56}$ Accordingly, Birss, J. ordered a hearing in "a few weeks' time" to determine whether, by then, Huawei had entered into a license agreement with Unwired Planet at the rates he specified and, if not, to consider, and likely issue, the injunction.

\section{Conclusion}

In Unwired Planet v. Huawei, Birss, J. adopts a balanced and well-reasoned approach to determining FRAND royalties and assessing the parties' contractual and competition law obligations in the face of FRAND commitments. In doing so, he takes several important theoretical stands, which could have significant implications for the manner in which such cases are decided and how parties interact during FRAND negotiations. Specifically, Birss, J. holds that there is but a single FRAND royalty rate applicable to any given set of SEPs and circumstances, but does not fault the parties for failing to pinpoint that rate in their initial offers or negotiations. Abuse of dominance under Section 102 TFEU, he reasons, does not occur under Huawei v. ZTE unless a SEP holder's offer is significantly above the true FRAND rate. Likewise, he rejects the idea of "hard-edged" non-discrimination, concluding that even if a SEP holder has granted another licensee a lower royalty rate, an implementer may not challenge its own FRAND license so long as the difference does not distort competition between the two licensees. While I do not necessarily agree with all of his conclusions, I applaud Birss, J.'s careful

${ }^{50}$ See Jason R. Bartlett and Jorge L. Contreras, Rationalizing FRAND Royalties: Can Interpleader Save the Internet of Things, _ REV. LITIG. _ (2017, forthcoming).

${ }^{51}$ In re Innovatio, 2013 U.S. Dist. LEXIS 144061, at *83.

${ }^{52}$ Apple Japan Godo Kaisha v. Samsung Electronics Co., IP High Court of Japan (May 16, 2014). See discussion in Bartlett \& Contreras, supra note 50.

${ }^{53}$ Unwired Planet at 9178.

${ }^{54}$ Unwired Planet at $9 \uparrow 264-272$. For a discussion of the usefulness and enforcement of such public patent "pledges", see Contreras, Market Reliance, supra note 7.

${ }^{55}$ Unwired Planet at $\uparrow \uparrow \mid 325$ et seq.

${ }^{56}$ Unwired Planet at $9807(18)$. 
and balanced reasoning in Unwired Planet v. Huawei. I expect that it will become an important touchstone for courts around the world as they wrestle with the complex issues that arise in FRAND royalty cases, especially as increasing numbers of SEPs are transferred to, and enforced by, patent assertion entities. 